\title{
3 ．治験依頼者の役割と範囲
}

\author{
日本製薬工業協会 \\ 衣 非脩*
}

\section{1. 新 GCP での治験依頼者の責務の概要}

(Table 1)

新 GCP に規定された治験依頼者の責務の概要 を Table 1 に示した. 主なものを挙げただけでも 15 項目になり，旧 GCP と大きな違いになってい る.

以下に，省令 GCP の “治験の依頼” と “治験の 管理”に関する基準から見た治験依頼者の役割に ついて, 答申 GCP の内容も適宜折り込みながら 述べる。

\section{2.「治験の依頼に関する基準」の内容との関係} (Table 2)

1 ）治験の依頼，管理に係る業務手順書の作成 業務手順書（SOP） は品質保証・品質管理の基 本となるものの一つであるが，旧 GCP の治験依 頼者の章にはこれに相当する規定はなかった．答 申 GCP は，治験依頼者は治験が適正に行われる ことを保証するために，手順書に基づく品質保証 および品質管理システムを履行し，保持する責任 を有すると規定しており，治験の依頼と管理に関 する業務の全てについて手順書を作成する必要が ある. 主なものとして, 治験実施計画書の作成と 改訂, 実施医療機関・治験責任医師の選定, 治験 薬概要書の作成と改訂, 治験の適否判定, 症例報 告書の変更・修正, データの取扱い, 治験薬の管 理・交付，実施医療機関での治験薬管理，安全性

* 武田薬品工業株式会社 于 103-8668 東京都中央区日本橋 2-12-10
情報の収集・評価と通知/報告，モニタリング・監 査の実施，原資料等の全ての治験関連記録の直接 閲覧，不遵守に対する措置，総括報告書の作成， 記録の保存などがある。

なお，記録の保存の手順書には，実施医療機関 や治験審査委員会が保存しなければならない記録 について，その保存の必要がなくなった場合に， その旨を実施医療機関長へ知らせることも含まれ ていなければならない.

2 ）治験の依頼，管理に必要な専門的知識を有 する者の確保・活用

治験依頼者の体制の問題であり, 新 GCP で初 めて規定された，治験業務の総括的な監督，治験 実施計画書 - 症例報告書・治験薬概要書の作成と 改訂, データの取扱いと検証, 統計解析, 総括報 告書の作成等の治験の全過程を通じて, 適格な者 (例えば生物統計学者, 臨床薬理学者, 医師等)に 業務を割り当てなければならない.また，治験に 関する医学的な問題について速やかに助言を得る ために，適格な医学専門家を指名することも求め られており，このような依頼者側の医学専門家の 氏名，職名等を治験実施計画書に記載しなければ ならなくなった，医学専門家は依頼者内部の者だ けではなく外部の者であってもよいとされてい る.

3 ）治験の依頼に必要な非臨床試験，臨床試験 の終了

被験薬の品質, 毒性, 薬理作用に関する試験や 臨床試験など, 治験の依頼に必要な試験を終了し ていることである．臨床試験も含め, 終了してお 
Table 1 治験依頼者の主な責務
1) 治験に関する全般的な運営・管理責任
2）品質保証 $(\mathrm{QA})$ ，品質管理 $(\mathrm{QC})$ システムを履行・保持
3 ）治験の依頼・管理業務の全過程に医学その他の専門家を確保・活用
4 ）治験の依頼に必要な非臨床試験，臨床試験を終了
5 ) 治験薬概要書を作成・改言
6）要件を満たした治験貫任医師，実施医療機関を選定
7 ）治験貴任医師と協議の上, 治験実施計画書を作成・改訂
8 ）被験者の健康被害を補償するのに必要な措置
9 ）治験薬 GMP に則り製造された治験薬, 治験薬管理手順書等を交付
10）効果安全性評価委員会, 治験調整医師・委員会を必要に応じ設置
11）モニタリング・監查を実施，原資料等の全ての治験関連記録を直接閲覧
12）被験薬の品質・有効性・安全性等に関する情報を収集, 評価, 伝達
13）適正な治験に支障を及ほした場合には，契約を解除し治験を中止
14）治験の総括報告書を作成
15）治験の依頼・管理に関する業務の一部を委託可能

くべき試験の内容は, 計画している治験のフェー ズ (目的), 治験薬の用法・用量, 投与期間, 被験 者の選択基準等を考慮して, 治験依頼時点の科学 的水準に照らして適正なものでなければならない のは当然である。これに関連して答申 GCP に， 「治験依頼者は, 計画している治験の目的, 当該治 験で採用される投与集団，用法・用量，投与期間， 観察項目，評価項目等の妥当性を支持できるだけ の十分なデータが非臨床試験, 先行する臨床試験 から得られており, 当該治験の倫理的・科学的妥 当性が裏付けられていることを保証しなければな らない。また，そのための手続きを文書で定める ものとする.」との規定がある．旧 GCP にあった 依頼者が行う治験の適否判定と軌を一にするもの であるが，保証のための手続きをどのようにする かは，新 GCP では依頼者が自らの責任で定める ことになる。

4 ）要件を満たした実施医療機関，治験責任医 師の選定

治験責任医師および実施医療機関を選定する責 任が治験依頼者にあることが新 GCP で初めて明 確にされた。それぞれの要件は別に定められてい るが，実施医療機関については旧 GCP のマニュ アルとほほ同様であるのに対し，責任医師につい
てはより詳細で新たな事項も加わっている，例え ば，治験を適正に行うことのできる十分な教育・ 訓練を受け, 十分な臨床経験を有すること, 治験 薬の適切な使用法に精通していること, 合意され た期間内に治験を適正に実施し，終了するのに必 要な時間的余裕を有し，必要数の適格な被験者を 集めることができること，十分な数の治験分担医 師と治験協力者を確保でき, また適切な設備を利 用できること，などである.

責任医師とは, GCP で定められた責務を実質的 に履行し得る者という意味であり, 教授とか部長 といった組織の責任者という意味ではない.した がって, 組織の役職者が名目的に責任医師になる のは好ましくない．実際の選定に当たっては，こ の点も含め, 事前に十分な調査を行うことが肝要 である。

\section{5 ）治験実施計画書の作成・改訂}

治験実施計画書（プロトコル）の作成・改訂が, 治験総括医師の廃止に伴い治験依頼者の責務と なったのも, GCP の大きな改正点の一つである. プロトコルに一般的に記載すべき重要な項目は答 申 GCP にかなり詳しく規定されており，原資料 等の全ての治験関連記録の直接閲覧も挙げられて いる。これに関連して, 症例報告書に直接記入さ 
Table 2 GCP 省令等の内容

第 2 章 治験の依頼に関する基準（第 4 条〜第 15 条）

(1) 治験の依頼，管理に係る業務手順書の作成

(1) 治験実施計画書の作成, (2) 医療機関・治験責任医師の選定, (3) 治験薬 の管理，(4)副作用情報等の収集，(5) 記録の保存，等)

(2) 治験の依頼，管理に必要な専門的知識を有する者の確保・活用

(適格な医師, 薬剤師, 生物統計学者, 臨床薬理学者, その他)

(3) 治験の依頼に必要な非臨床試験, 臨床試験の終了

（当該治験の倫理的，科学的妥当性を裏付けるだけの十分なデー夕）

(4) 要件を満たした実施医療機関, 治験責任医師の選定

(5) 治験実施計画書の作成・改訂

(1) 原資料等の直接閲覧に係る事項, 代諾者の同意に基づく非治療的治験 に係る事項, 事前同意が得られない緊急状況下の治験に係る事項, 等, (2) 治験責任医師と協議し, 計画書の内容とその遵守につき同意取得)

(6) 治験薬概要書の作成・改訂

(7) 同意・説明文書の作成依頼, 受領 （必要な資料・情報を提供，作成に協力，受領）

(8) 実施医療機関の長への文書の事前提出

(1) 治験実施計画書・症例報告書, (2) 治験䒩概要書, (3) 同意・説明文書,

(4) 責任医師・分担医師の履歴書等, (5)治験費用・被験者の健康被害補償の 説明文書, 等)

(9) 治験薬の事前（治験契約締結前）交付の禁止

(10) 治験の依頼，管理に係る業務の一部を委託する場合の契約

(11) 実施医療機関との治験の契約（業務受託者を含む）

(1) 委託業務の範囲, (2) 治験薬の管理, (3) 依頼者及び医療機関従事者が行 う通知, (4) 秘密保全, (5)治験費用, (6)プロトコル遵守, (7) 記録の保存,

(8) 原資料等の直接閲覧, (9) 契約の解除, (10) 健康被害の補償, (11) その他必 要な事項)

(12) 被験者の健康被害を補償するのに必要な措置

れ，かつ原データと解すべき資料を特定すること が求められている。しかし，一旦特定するとその デー夕には原資料がないということになり，直接 閲覧に重大な影響を及ぼすことにもなるので，特 定は慎重に行う必要がある.

非治療的な治験を代諾者の同意に基づいて行う 場合（例えば小児での薬物動態試験）や，緊急状 況下の救命的な治験を被験者および代諾者から事 前の同意を得るのが困難な条件のもとで行う場合 には, プロトコルの記載内容に特別の注意が必要 である。

プロトコルの作成・改訂に当たっては，治験責 任医師とプロトコルと症例報告書の案について協
議し, それらの内容と当該プロトコルを遵守して 治験を行うことについて責任医師と合意する必要 がある.この場合, 依頼者と責任医師の双方に, 同意または拒否の権限があることを明確にしてお くことが重要である．双方が安易な妥協を重ねて 合意することは，責任の所在を曖昧にするので避 けなければならない。特に依頼者には，作成の最 終責任を負っているだけに，責任医師の意見に納 得できないときは思い切って治験の依頼を断念す るだけの決意が求められる.

以上のごとく，プロトコルの作成・改訂は，依 頼者が主体性をもって進めなければならなくなっ た．依頼者は医学専門家をはじめとする専門家を 
確保し活用することが求められている上に，効果 安全性評価委員会の設置や治験調整医師の委嘱も 可能であるので，その限りでは専門家の指導や助 言を得ながら進めるという点はこれまでと基本的 に変わりはない．しかし，依頼者に最終決定の責 任があるところが異なっているので，依頼者は主 体性のある判断を下せるだけの能力を持たなけれ ばならないことになる。

\section{6 ）治験薬概要書の作成・改訂}

治験薬概要書の記載事項も, これまで以上に詳 細であることが必要となり, 具体的内容や作成上 の注意が答申 GCP に定められている.

治験薬との因果関係が否定できない有害事象 が, 予測できないものであるかどうかは, 概要書 に記載されているものと性質や重症度などが一致 しているかどうかで判定することになっているの で,この面からも概要書は重要である。概要書は 常に更新しておく必要があり，少なくとも年に 1 回は見直すとともに, 被験薬や適正な治験の実施 に関連する新たな情報が得られたときは, 必要に 応じて改訂しなければならない. 特に重要な情報 が得られた場合には, 改訂に先立ち, 治験責任医 師, 実施医療機関の長などに報告する必要がある.

7 ）同意・説明文書の作成依頼，受領

旧 GCP では治験総括医師が治験依頼者と協議 して説明文書を作成または改訂することになって いたが，新 GCP では治験責任医師が依頼者の協 力を得て同意・説明文書を作成または改訂するこ とになった，実施医療機関に治験の依頼をするに は, 事前に必要な資料・情報を添えて責任医師に 同意・説明文書の作成を依頼しなければならない。 責任医師によって作成・改訂された説明文書は依 頼者に提出されるが, 受領した段階で依頼者は内 容を確認し，問題があれば責任医師にその旨を伝 え, 修正について協議する必要がある. GCP 上不 適切であれば，折角のデータが申請資料として受 け入れてもらえなくなる可能性が高いからであ る.

8 ) 実施医療機関の長への文書の事前提出

実施医療機関に治験の依頼を行うに当たって は，治験貴任医師と合意したプロトコル，症例報
告書の様式, 治験薬概要書, 責任医師が作成した 同意・説明文書，責任医師・治験分担医師の履歴 に関する資料，治験費用に関する資料，被験者の 健康被害に対する補償に関する資料，被験者の募 集手順に関する資料, 被験者への支払いがある場 合はそれに関する資料，その他医療機関が必要と する資料を，医療機関の長に提出しなければなら ない.これらの資料は, 治験審査委員会での審査 対象ともなるものである.

また，治験審査委員会の審査結果を確認するた めに，医療機関の長から，委員会の意見を記した 日付入り文書の写し，委員会の意見に基づく医療 機関の長の指示・決定の文書, 委員会の名称と所 在地が記された文書, 委員会が GCP に従って組 織され活動している旨を委員会自ら確認した文書 などを, 治験の契約を締結する前に入手する必要 がある。

9 ）治験薬の事前（治験契約締結前）交付の 禁止

治験依頼者は，実施医療機関との間で治験の契 約が締結されるまでは, 当該医療機関に治験薬を 交付してはならないというものである.

なお, 薬事法と薬事法施行規則に従い, 医療機 関と治験の契約を締結する前に，厚生大臣に治験 の計画を届け出なければならない.

10）治験の依頼, 管理に係る業務の一部を委託 する場合の契約

治験依頼者の業務の一部を委託できることが新 GCP によって初めて可能になったが, その場合は 委託した業務について文書による契約を締結しな ければならないというものである. 契約書には委 託業務の範囲を明記する必要があり, 明確に委託 されていないものは全て依頼者の業務と見なされ る. 受託者（CRO）は委託された業務を GCP に 従って行う必要があるのは当然であるが, 治験 データの品質と完全性に関する最終責任は依頼者 が負うことになるので, CRO も品質保証・品質管 理を履行しなければならない.このことを確実な ものとするため, 契約書には委託された業務を行 う手順と，手順に基づいて当該業務が適正，円滑 に行われているかどうかを依頼者が確認できる旨 
を取り決めておく必要がある.

なお, 省令第 12 条の業務委託は, 第 13 条の規 定からみて三者契約をしなければならない範囲を 指しており,依頼者との二者だけに係わる業務で， 実施医療機関とは何ら関係のない業務の委託は含 まないと解釈される，換言すると，両条に該当す る業務を受託する者が GCP 上の CRO というこ とになる，GCP 上の CRO には該当しないが，医 療機関または依頼者が臨床検査の一部を外注する 場合も，必要に応じて検查施設も含めた三者契約 を締結することが望ましいと考えられる。

11）実施医療機関との治験の契約（業務受託者 を含む)

実施医療機関との治験の契約の内容は, 新 GCP により大幅に拡大された。すなわち, CRO に業務 を委託した場合の当該業務の範囲,治験薬の管理, 記録の保存，治験依頼者および医療機関従事者が 行う通知, 被験者の秘密保全, 依頼者に帰属する 情報の秘密の保全, 治験の費用, プロトコルの遵 守，モニタリング・監査ならびに治験審査委員会 と当局の調査の受入れ，原資料等の全ての治験関 連記録の直接閲覧，適正な治験に支障を及ほした 場合の依頼者による契約の解除，などである.

なお，契約を解除し治験を中止する場合であっ ても，すでに実施された治験についての当該医療 機関での記録は，GCP で定められた期間，当該医 療機関で保存されるよう契約しておく必要があ る. 治験データの所有権やその利用に関しても取 り決めておくことが望ましい.

12）被験者の健康被害を補償するのに必要な 措置

治験依頼者は，治験に関連して被験者に生じた 健康被害の治療に要する費用その他の損失を補償 するための手順を定め，その履行を確保するため に保険その他の措置を講じておかなければならな い，というものである。この場合の健康被害には CRO に委託した業務によって生じたものも含ま れる：保険は製造物責任保険に加入するのが一般 的であるが，答申 GCP の原則に，「健康被害が過 失によるものであるか否かを問わず，被験者の損 失は適切に補償されなければならない.その際,
因果関係の証明等について被験者に負担を課すこ とがないようにしなければならない.」とあること に留意する必要がある。これは補償を優先させる べきとの理念を述べたものとされている.

\section{3、「治験の管理に関する基準」の内容との関係}

(Table 3)

\section{1）治験薬の管理}

治験薬に表示すべき事項，表示してはならない 事項については, 従前の規則と基本的には変わっ ていない. 治験薬のコードや包装に関しては, 盲 検下に使用される治験薬にあっては，緊急時にど の薬剤か（被験薬か対照薬か）を治験責任医師等 が直ちに識別でき，かつ盲検性が破られたことを 検知できるようにしておくことが求められてい る.これは個別割り付け票のようなものではなく， 包装自体にそういう工夫をする，例えばコインで 擦れば薬剤名が出てくるといったものが想定され ている。また包装は，輸送や保存中の污染，劣化 の防止のみならず，使用の便宜も考慮したもので あることが求められているので, 治験依頼者はこ の点にも十分配慮する必要がある。

一方，依頼者は実施医療機関における治験薬の 管理に関する手順書を，治験の契約締結後遅滞な く医療機関の長または治験薬管理者に交付しなけ ればならない.手順書には, 治験薬の受領, 取扱 い, 保管, 管理, 処方, 未使用治験薬の被験者か らの返却および依頼者への返却その他の処分が適 切に行われるのに必要な指示を記載する。また， 治験薬の保存条件, 使用期限, 溶解方法, 注入方 法等の取扱い方法を説明した文書を，治験薬管理 者はもとより責任医師，治験分担医師，治験協力 者に交付する必要がある。

\section{2 ）治験薬の交付}

治験薬 GMP が制定（平成 9 年 3 月 31 日 薬発 第 480 号) されたため治験依頼者はこれに適合し た製造所で治験薬を製造し，適切な時期に実施医 療機関に交付する責任があるというものである. 販売業者その他の第三者を介在させることなく直 接交付することが求められているが，医療機関と 治験の契約をしている CRO が交付することは差 
Table 3 GCP 省令等の内容

第 3 章 治験の管理に関する基準（第 16 条〜第 26 条）

\section{(1) 治験薬の管理}

(1) 治験薬への記載禁止事項, (2) 盲検用治験薬に緊急時に識別可能な措置,

(3) 污染・劣化防止の包装, (4)治験薬の製造・交付等の記録の作成, (5) 治験 薬の管理手順書等を医療機関関係者に交付）

(2) 治験薬の交付

（GMP 適合製造所で製造された治験薬を医療機関に直接交付）

(3) 多施設共同治験

（1）細目調整業務を治験調整医師・委員会に委嘱することが可能，(2) 委嘱 業務の範囲・手順その他の必要事項を記した文書を作成)

(4) 効果安全性評価委員会の設置

(1) 治験継続の適否，プロトコルの変更等を手順書に従って審議，(2) 審議 の記録を作成・保存)

(5) 副作用情報等の取扱い

(1) 被験薬の品質・有効性・安全性等の必要な情報を収集・検討し医療機関 の長に提供, (2) 重篤・未知の副作用等を医療機関の長, 治験貴任医師に直 ちに通知, (3) 必要に応じ, プロトコル・治験薬概要書を改訂)

(6) モニタリングの実施

(11) 手順書に従ったモニタリング，(2) 原則として医療機関を訪問）

(7) モニターの貴務

(1) 治験が GCP・プロトコル不遵守であることを確認した場合はその旨を 直ちに治験責任医師その他に通告, (2) モニタリング報告書の作成, 提出)

(8) 監查の実施

(1) 計画書・手順書に従った監査，(2) 開発・モニタリング部門から独立，

(3) 監查報告書・監查証明書の作成, 提出)

(9) 治験の中止・中断, 開発の中止

（1）適正な治験に支障を及ほした場合は，契約を解除し治験を中止，(2)治 験の中断・中止，開発の中止を医療機関の長に文書で通知）

(10) 総括報告書の作成

（治験を終了／中止した場合に作成し，監査証明書を添付して保存）

(11) 記録の保存

(1) 治験依頼者が作成したプロトコル, 契約書, 総括報告書等の文書, (2) 治 験薬管理，モニタリング・監査その他の治験の依頼・管理に係る記録, (3) 医療機関から入手の治験審查委員会の意見, 症例報告書等の文書, (4) その 他，治験により得られたデー夕等)

し支えないとされており，また緊急に交付する必 要があり,かつその手段として運送業者等を利用 する場合などは，第三者を介在させたことに当た らないとされている.

\section{3 ）多施設共同治験}

多施設共同治験の場合に，治験調整医師または 治験調整委員会を置いて業務を委嘱できることに
なった，委嘱する業務は，プロトコルの内容の細 目についての施設間の調整や治験中に生じたプロ トコルの解釈上の疑義の調整等, 共同治験におけ る実施医療機関の調整に係る業務とされている. したがって,あくまで施設間の調整が基本であり, 治験依頼者の本来の責務であるプロトコルの作 成・改訂や治験成績の評価などを丸ごと委嘱する 
といったことは想定されていない．多施設共同治 験であっても，依頼者がプロトコルについて協議 するべき本来の相手は, 調整医師・委員会の有無 にかかわらず，個々の治験責任医師であることに 変わりはないことを忘れてはならない。

調整医師の選定については, 多施設共同治験に 参加する責任医師の中から選定されることが考え られるが, 必ずしも責任医師には限らないとされ ており，これは責任医師の中から選ぶのを原則と していると考えるべきである. 責任医師以外の医 師が調整医師になるのを例外としなければ，特定 の医師が多くの治験の調整医師になるという弊害 を生むことになるからである。なお，調整医師は 依頼者側の医学専門家とは立場を異にしているの で，同一の医師が両者を兼務することは適当では ない.

以上のことからも, 調整医師や調整委員会を置 く場合には, その業務の範囲, 手順その他必要な 事項を定めた文書を作成することが求められてい る.その中では, 調整医師と依頼者および調整医 師と他の責任医師の役割関係について明確にして おくことが望ましい.

答申 GCP には, 多施設共同治験に当たって依 頼者が保証すべきその他の事項も書かれている. それらの中では，施設間で評価や判定にバラツキ が生じないよう対策を講じておく点が特に重要と 考える。

4 ) 効果安全性評価委員会の設置

必要に応じて設置できるこの委員会は, 治験の 進行, 安全性デー夕, 重要なエンドポイントなど を適当な間隔で評価し,治験依頼者に治験の継続, 変更, 中止・中断を提言するための, 依頼者, 治 験責任医師, 治験調整医師から独立の委員会であ り，中間解析を行うことも想定されている．独立 性を保持することが重要であるので, 答申 GCP では委員会自身が業務手順書を作成し，会合の記 録も作成することになっているが，省令 GCP で はともに依頼者が作成するとなっている，実際に は, 依頼者が委員会と協議して手順書を作成し, 委員会の了承のもとに審議や会合の記録を作成す ることになろう。記録は依頼者が保存しなければ
ならない.

5 ）副作用情報等の取扱い

旧 GCP にもあったが, 被験薬の品質, 有効性, 安全性その他の治験を適正に行うのに必要な情報 を収集，評価，検討し，その結果を全ての実施医 療機関の長に提供するのが, 治験依頼者に課せら れた基本的責務である。 また必要に応じて，プロ トコル, 治験薬概要書を改訂し, 医療機関の長に 提出しなければならない.

その上で, 薬事法第 80 条の 2 第 6 項に基づく施 行規則第 66 条の 7 に規定された重篤で予測でき ない副作用等を知ったときは，定められた期限内 に厚生大臣宛に報告するとともに, 治験に関与す る全ての責任医師，医療機関の長にも直ちに通知 する必要がある。通知を受けた医療機関の長は, 直ちに治験審査委員会に文書で通知し, 治験を継 続することの適否について治験審査委員会の意見 を聴かなければならないことになっている。

6 ）モニタリングの実施，ならびに

7 ) モニターの責務

新 GCP により，漸くモニタリングが明文化さ れた。答申 GCP にモニタリングに関して詳細な 規定があるように，モニタリングは治験依頼者の 治験管理業務の中でとりわけ重要な役割を果たす ものである。

モニタリングの目的は, 被験者の人権, 安全お よび福祉が保護されていること, 治験がプロトコ ルと GCP を遵守して行われていること, 治験責 任医師等から報告されたデータ等が正確かつ完全 で，原資料等に照らして検証できることなどを確 認することにある．依頼者にはモニタリングが適 切に行われていることを保証する責務があるの で，適切な訓練を受け，十分にモニタリングする のに必要な科学的, 臨床的知識を有する者をモニ ターに指名しなければならない.モニターがプロ トコル，同意・説明文書， GCP 等を熟知していな ければならないのは当然である。

同時に依頼者は，モニターが従うべきモニタリ ングに関する標準業務手順書を作成しなければな らないが，併せて当該治験に特有の手順書も作成 する必要がある。モニタリングの範囲や方法は, 
治験の目的, デザイン, 複雑さ, 盲検性, 被験者 に対する危険性のレベル，規模およびエンドポイ ントなどによって変わり得るからである。答申 GCP にはモニターが確認すべき事項として 16 項 目書かれており，この中から依頼者が当該治験に とって必要と考えるものを選んでモニターに指示 してもよいことになっているが，一般的には省略 可能なものはほとんどないように思われる.

モニタリングは, 治験の開始前, 実施中, 終了 後に責任医師, 実施医療機関その他の治験関連施 設を訪問して行うのが原則であるが，大規模試験 などでは例外的に中央モニタリングという方式を 採ることが認められている。

プロトコルや GCP からの逸脱事項が見出され た場合, モニターは責任医師のみならず必要に応 じて医療機関の長にもその旨を伝え, 逸脱の再発 を防止するための適切な措置を講じなければなら ない.

\section{8 ）監査の実施}

旧 GCP にも監査はあったが，専ら治験依頼者 内部での監査であり, 治験の依頼先に対する監査 の明文化は新 GCP からである. 監査は, 治験がプ ロトコル, GCP および業務手順書に従って実施さ れ, デー夕が正確に記録, 解析され, 報告されて いるか否かを体系的に評価する品質保証の業務で あり, 治験に直接係わる業務から分離・独立して 行われるところに特徵がある，つまり，治験の依 頼に関する業務やモニタリングを含む治験の管理 に関する業務が適切に行われているかどうかも監 查の対象になるので, 監査を担当する者は開発部 門やモニタリング担当部門に属してはならないと されている.

依頼者が教育・訓練・経験によって監査を適切 に行い得る者を監査担当者に指名し, 監査担当者 が依頼者によって作成された監査手順書と，それ に基づく監査計画書に従って監査を行う. 個々の 治験に対する監査は, 治験の申請上の重要性, 被 験者数, 複雑さ, 被験者に対する危険性のレベル や，モニタリングなどで見出された問題点等を考 慮して監査の対象, 時期等を決定する. 監查担当 者は，監查で確認した事項を記録した監査報告書
および監査を実施したことを証明する監査証明書 を作成して依頼者に提出しなければならない。

モニタリングと監査に共通する重要な業務に原 資料等の全ての治験関連記録の直接閲覧がある. これは依頼者に提出された症例報告書等の報告書 や通知と実施医療機関にある原資料等の全ての治 験関連記録とを照合することにより, GCP および プロトコルで要求されている症例報告書等の全て の報告/通知が適切な時期に提出されており,かつ 必要とされるデータその他の情報が漏れなく正 確, 完全に記載されているか否かを確認するのを 最終の目的としている. 医療関係者の守秘義務と の関係が問題となるが, 新 GCP において医療機 関や治験責任医師はモニタリングや監查に協力 し，原資料等の全ての治験関連記録を直接閲覧に 供しなければならないとされており，また被験者 からプライバシー保護のもとに被験者の医療記録 が直接閲覧されることについて事前に同意を得て おかなければならないと定められているので, こ の限りにおいて医療関係者の守秘義務は問われな いことになった.しかし，依頼者や CRO には薬事 法において守秘義務が課せられている.

直接閲覧の対象になるのは原資料のみではない ことに改めて留意する必要がある。同意・説明文 書, 治験審査委員会から入手した文書, 治験薬管 理の記録，その他の治験に関連する全ての記録が 含まれる。しかもその中の原資料とは, 症例報告 書その他の報告書の元になった全ての資料であ り, 診療録（カルテ）が主要なものではあっても それのみを指すのではない. 直接閲覽の目的を十 分に果たすためには，まず原資料等の全ての治験 関連記録が整備・保存され，かつ正しいものであ ることを確認した上で，それらと提出された全て の報告書/通知を照合するという二段階を踏むこ とが不可欠であり, 前者を飛ばし単にカルテと症 例報告書の照合だけすればよいというものではな い.

9 ）治験の中止・中断, 開発の中止

治験依頼者が治験を中止・中断する，あるいは 被験薬の開発を中止する場合は, その理由を付し て速やかに実施医療機関の長と厚生省に通知/報 
告しなければならない。.また，モニタリングや監 査などにより医療機関が GCP, プロトコル, 治験 の契約に重大または継続して違反していることが 発見された場合は, 治験の契約を解除し, 当該医 療機関での治験を中止し，厚生省にその旨を速や かに報告する必要がある。

10）総括報告書の作成

治験を終了または中止したときは，総括報告書 の作成に関する業務手順書および「治験の総括報 告書の構成と内容に関するガイドライン」(平成 8 年 5 月 1 日 薬審第 335 号) に従って治験依頼者が 自ら総括報告書を作成し，規制当局の求めに応じ て提出できるように保存しておかなければならな くなった。なお，総括報告書には監查証明書を添 付しておく必要がある.

11）デー夕の取扱い

省令 GCP には規定されていないが，データの 取扱いについて付言する。答申 GCP は，「治験依 頼者は，治験に関連する全てのデータの信頼性と その適正な処理を保証するために，データの取扱 いの各段階に品質管理を適用しなければならな い.」としている. 具体的には, (1) 電子デー夕処理 システムのバリデーション, セキュリティ, バッ クアップ等を, 手順書を整備して確実なものとす ること，(2)被験者を識別できる明確な被験者識別 コードを用いること, (3) 治験の実施に先立って治 験責任医師等に症例報告書の変更又は修正に関す る手引きを提供し，それに従ってもらうこと，(4) 依頼者が指名した者，例えばモニターによって行 われた症例報告書の変更・修正が，文書に記録さ れ，必要なものであり，かつ責任医師が承認した ものであることを保証するための手順書を作成し ておくこと，などである. (4)は単純で明白な記載 ミスを修正・変更する場合のことを指している。

\section{4. 治験依頼者の体制整備}

新 GCP により治験依頼者の役割の範囲が大幅 に拡大した，依頼者は責務を遂行できるよう体制 を整備しなければならない。その主なものは，

1 ）意思決定の権限と責任の所在を明確にする

2 ）品質保証・品質管理のシステムを構築し, 機能を強化する

3 ）治験の依頼と管理に関する業務手順書を整 備して遵守する

4 ）適格な専門家を確保し，特に，開発計画， プロトコル，データの解析等を適切なものと する

5 ）社内関連部門の間の連携を強化し, 研究開 発から市販後にわたり一貫した対応を図る

6 ）治験の依頼と継続の適否を自らの責任で厳 正に判定する

特に，被験薬が治験を依頼するのに值する だけの独創性，新規性，医療上の必要性等の 特性を十分に備えているかを厳しく評価する 7 ) 治験開始後, 被験薬の有効性, 安全性, 品 質に関する情報を継続的に収集, 評価, 伝達 できる体制を整備する

8 ）モニター, 監查担当者の教育研修を徹底し, 資質の向上を図る

などである。

以上，新 GCP によって定められた責務を中心 に, 治験依頼者に課せられている役割について述 べた. 治験は多くの関係者との協同作業によって 初めて成り立つものであるので，これら関係者か ら信頼を得ながら，依頼者としての役割を全うで きるよう努力を重ねていきたい. 